IRA-International Journal of Management \& Social Sciences

ISSN 2455-2267; Vol.03, Issue 03 (2016)

Institute of Research Advances

http://research-advances.org/index.php/RAJMSS

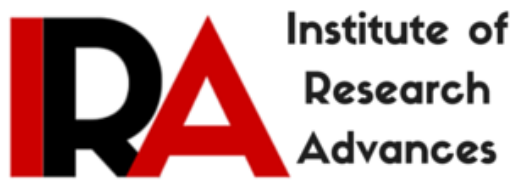

\title{
A Comparitive Study on Working Capital Management of Selected Pharmaceutical Companies in India
}

\section{Dr. M. Viswanathan}

Principal (I/C) and Head, Department of Commerce,

Karuppannan Mariappan College, Muthur-638105, India.

Dr. A. Palanisamy

Assistant Professor, Department of Commerce (CA),

Karuppannan Mariappan College, Muthur-638105, India.

\section{Mr. R. Mahesh}

Assistant Professor, Department of Commerce (CA),

Karuppannan Mariappan College, Muthur-638105, India.

DOI: http://dx.doi.org/10.21013/jmss.v3.n3.p11

\section{How to cite this paper:}

Viswanathan, D., Palanisamy, D., \& Mahesh, R. (2016). A Comparitive Study on Working Capital Management of Selected Pharmaceutical Companies in India. IRAInternational Journal of Management \& Social Sciences (ISSN 2455-2267), 3(3). doi:http://dx.doi.org/10.21013/jmss.v3.n3.p11

(C) Institute of Research Advances

(cc) EY-NC

This works is licensed under a Creative Commons Attribution-Non Commercial 4.0 International License subject to proper citation to the publication source of the work.

Disclaimer: The scholarly papers as reviewed and published by the Institute of Research Advances (IRA) are the views and opinions of their respective authors and are not the views or opinions of the IRA. The IRA disclaims of any harm or loss caused due to the published content to any party. 


\section{ABSTRACT}

Working capital management refers to management of current assets and of current liabilities. Every company may have an optimal level of working capital that maximizes their value. Prior evidence has determined the relationship between working capital and performance. The working capital management was determined by the cash conversion period and position of working capital, indicated by profitability and liquidity analysis. As the data selected for the study consists of observations in a time series manner so, analytical method is used in this study. Ten companies were selection during the study period is confined only 10 years from 2003-2004 to 2012-2013. The financial and statistical tools used for the study were Ratio Analysis, Descriptive Statistics and Indices. Results indicate that high investment in inventories and receivable lead to lower profitability and current assets to total assets lead to higher profitability. The results conclude that a strong relationship between working capital management and financial position of selected pharmaceutical companies in India.

Key Words: Liquidity Ratios, Turnover Ratio, Profitability Ratios, Business and Pharmaceutical Companies.

\section{Introduction}

In this chapter an attempt has been made to evaluate the analysis of working capital position of the selected Pharmaceutical companies. In order to evaluate the working capital position of any enterprise, the financial analyst needs certain yardsticks. One of such yardsticks frequently used is a ratio. Ratios, as a tool of financial management, can be expressed as percentage or fraction and stated that comparison between the numbers. Ratio analysis provides guides and clues especially in spotting trends towards better or poor performance and in finding out significant deviation from any average or relatively applicable standard. The analysis of working capital position has been divided into two main sections. In the first section, the financial ratios of various selected Pharmaceutical companies are calculated and examined like analysis of profitability; liquidity and analysis of activity ratios are exhibited. The second section deals with determinants of profitability in respect with liquidity by selected independent variables also analyzed.

\section{Objectives of the study}

The study is designed to achieve the following objectives:

(i) To assess the working capital position of the selected Pharmaceuticals companies.

(ii) To examine the working capital state of affairs of the selected Pharmaceuticals companies.

(iii) To test the working capital strengths and weaknesses of selected Pharmaceuticals firms.

(iv)To pinpoint the causes of poor working capital position and suggest some measures to overcome the problems. 


\section{Methodology}

A scientific approach to the research methodology is very much essential to evaluate the research problem systematically. In the present study, the data used for secondary in nature and the required data were collected from the compilation made by the Centre for Monitoring Indian Economy (CMIE) for the period from 2003-2004 to 2012-2013. Prowess database of CMIE is the most reliable and empowered corporate database. The annual published financial reports of the companies have been used for random checking of the data.

\section{Sample Design}

As the complete source list of all the Pharmaceutical Companies is 174 listed companies as per the latest Balance Sheet available, the data for this study is selected based on convenience sampling method. The criteria while selecting the Pharmaceutical companies' Total Assets (Rs in Cr.) is an appropriate factor to determine the Financial Performance of the company. For the purpose of this study, the set of the Pharmaceutical companies are determined using the criteria stated as below;

1. The companies which hold Total Assets of more than of Rs 5,000 Cr. is categorized as Large Scale Pharmaceutical Companies.

2. The companies which hold Total Assets of more than of Rs 2,500 Cr. and less than of Rs 5,000 Cr. is categorized as Medium Scale Pharmaceutical Companies.

This study has classified into Large Scale and Medium Scale Pharmaceutical Companies the list of sample companies in Table 1.1.

Table 1.1 Sample Selection of Pharmaceutical Companies (Values as on $31^{\text {st }}$ March 2013)

\begin{tabular}{|l|l|c|l|l|c|}
\hline \multicolumn{3}{|c|}{ Large Scale Companies } & \multicolumn{3}{c|}{ Medium Scale Companies } \\
\hline $\begin{array}{c}\text { Name of the } \\
\text { company }\end{array}$ & $\begin{array}{c}\text { Registered } \\
\text { State }\end{array}$ & $\begin{array}{c}\text { Total } \\
\text { Assets } \\
\text { (Rs in } \\
\text { Cr.) }\end{array}$ & $\begin{array}{c}\text { Name of the } \\
\text { company }\end{array}$ & $\begin{array}{c}\text { Registered } \\
\text { State }\end{array}$ & $\begin{array}{c}\text { Total } \\
\text { Assets } \\
\text { (Rs in } \\
\text { Cr.) }\end{array}$ \\
\hline 1.Piramal Enter & Maharashtra & 15297.99 & 1.Jubilant Life & Uttar Pradesh & 4897.88 \\
\hline $\begin{array}{l}\text { 2.Dr.Reddys } \\
\text { Labs }\end{array}$ & Hyderabad & 9916.00 & $\begin{array}{l}\text { 2.Cadila } \\
\text { Health }\end{array}$ & Gujarat & 3908.50 \\
\hline 3. Cipla & Maharashtra & 9912.81 & 3.Glenmark & Maharashtra & 3188.78 \\
\hline 4.Sun Pharma & Punjab & 8249.56 & $\begin{array}{l}\text { 4.Orchid } \\
\text { Chemical }\end{array}$ & Tamil Nadu & 3244.65 \\
\hline 5.Ranbaxy Labs & Gujarat & 8042.15 & 5.Divis Labs & $\begin{array}{l}\text { Andhra } \\
\text { Pradesh }\end{array}$ & 2588.70 \\
\hline
\end{tabular}

Source: Compiled from Annual Reports of the respective companies.

\section{Tools for Analysis}

The financial and statistical tools used for the study were Ratio Analysis, Descriptive Statistics. . The techniques such as arithmetic mean, standard deviation, coefficient of variation, growth rates, annual growth rate, compound annual growth rate, analysis of variance, Pearson's correlation analysis and multiple regression analysis. 


\section{Period of the Study} 2012-2013.

The study covers a period of ten years from the financial year 2003-2004 to

\section{Limitation of the study}

1. The study is restricted and limited to sample size of 10 selected pharmaceutical companies in India.

2. The effect of inflation has not been considered in the present study.

3. The result of analysis is subject to the same constraints as are applicable to statistical tool.

4. The study period is confined only 10 years from 2003-2004 to 2012-2013.

\section{Review of literature}

Mobeen Ur Rehman and Naveed Anjum(2013) ${ }^{1}$ empirically examine the effects of working capital management on the profitability of Pakistan cement industry. Secondary Data was collected from Annual Reports and the sample size is 10 consisting of Pakistan cement Companies listed in KSE from 2003-2008. The relationship between working capital management and profitability is examined using statistical tools. The result accepts the hypothesis that there is a positive relationship between working capital management and profitability on the cement sector of Pakistan.

Gulshan Kumar (2013) ${ }^{2}$ in his study makes an effort to investigate growth pattern and productivity trends of small-scale non-metallic mineral products industry in Punjab. The growth of industry has been measured in terms of four variables namely: number of units, fixed investment, direct employment and production. Yearly growth rates have been computed to mirror year-to-year fluctuations in growth and compound annual growth rates (CAGRs) have been worked out to find the impact of the policies of liberalized regime on growth of this industry. The study observed that the significant growth rate was observed in the variables namely number of units, fixed investment and production. But the policies of liberalized regime have resulted in qualitative rather than quantitative growth in the small scale non-metallic minerals products industry in Punjab. Highly significant growth rate was recorded in fixed investment and production, a slow growth was noticed in number of units but insignificant growth was gauged in employment during the liberalization period.

Muhammad FahadIftikhar (2013) ${ }^{3}$ his study was conducted to determine the determinants of working capital management efficiency of automotive and engineering firms listed in Karachi Stock Exchange of Pakistan. The Cash

${ }^{1}$ Mobeen ur rehman,naveed anjum(2013), "determination of the impact of working capital management on profitability" an empirical study from the cement sector in pakistan asian economic and financial review,, 3(3):319- 332.

2 Dr.Gulshan Kumar Global (2013), "Journal of Science Frontier Research" Volume 11, Issue 2, March 2012, pp: 99-120.

3 Muhammad FahadIftikhar, (2013)"Determinants of working capital management efficiency: Case study of Pakistani automotive and engineering firms listed in Karachi Stock Exchange", Research Journal of Finance and Accounting, Vol.4, No.7, pp: 216236. 
Conversion Cycle, Days sales Inventory, Days Payable Outstanding and Days Sales Outstanding are the explanatory variables. Whereas the descriptive statistics, Pearson's Bivariate correlation analysis and ordinary pooled least square with fixed effect model were applied to investigate the significance of panel data set. It is quarterly based and secondary data in nature that comprises of 9 firms for 5 years. The observations were taken from financial years 2006 to 2010 of the listed firms. It is concluded that to keep the working capital efficient cash conversion cycle must be shortest. For this there is need of tight collection policy and liberal payment policy while the inventory management must be efficient by reviewing the inventory policy. It is concluded that it is also an efficient factor for efficient cash conversion cycle and working capital management efficiency.

\section{Theoretical Model Framework}

The results of the selected companies financial ratios regarding to profitability, liquidity and turnover ratios for the purpose to prove the hypothesis two-way ANOVA has been applied for the following null hypothesis:

$\mathbf{H}_{\mathbf{0}}$ : There is no significant difference between the selected ratios, among the selected 


\section{Table 1.2}

\section{LIQUIDITY RATIO OF SELECTED PHARMACEUTICAL COMPANIES}

Table 1.2 Liquidity Ratios of Selected Pharmaceutical Companies

\begin{tabular}{|c|c|c|c|c|c|c|c|c|c|c|}
\hline \multicolumn{11}{|c|}{ CURRENT RATIO OF SELECTED PHARMACEUTICAL COMPANIES } \\
\hline & \multicolumn{5}{|c|}{ Large Scale Companies } & \multicolumn{5}{|c|}{ Medium Scale Companies } \\
\hline & $\begin{array}{c}\text { Piramal } \\
\text { Enterprises }\end{array}$ & $\begin{array}{c}\text { Dr. } \\
\text { Reddy's } \\
\text { Lab }\end{array}$ & CIPLA & $\begin{array}{c}\text { Sun } \\
\text { Pharma }\end{array}$ & Ranbaxy & $\begin{array}{c}\text { Jubilant } \\
\text { Life }\end{array}$ & $\begin{array}{l}\text { Cadila } \\
\text { Health }\end{array}$ & Glenmark & Orchid & $\begin{array}{l}\text { Divis } \\
\text { Labs }\end{array}$ \\
\hline Average & 2.44 & 3.2 & 3.1 & 4.25 & 1.69 & 1.91 & 2.11 & 5.02 & 2.63 & 3.07 \\
\hline SD & 0.62 & 0.69 & 0.63 & 2.02 & 0.37 & 0.37 & 0.3 & 2.74 & 0.73 & 0.4 \\
\hline $\mathrm{CV}$ & 25.41 & 21.63 & 20.23 & 47.61 & 21.68 & 19.45 & 14.05 & 54.49 & 27.66 & 13.12 \\
\hline Maximum & 3.4 & 3.91 & 3.72 & 7.92 & 2.19 & 2.46 & 2.58 & 8.88 & 3.64 & 3.76 \\
\hline Minimum & 1.43 & 2.15 & 2.11 & 2.57 & 1.21 & 1.23 & 1.79 & 1.56 & 1.78 & 2.56 \\
\hline AGR (\%) & 52.96 & -14.11 & 72.95 & -2.22 & -38.21 & -47.51 & 3.58 & -55.19 & -20.22 & -12.12 \\
\hline $\operatorname{CAGR}(\%)$ & 4.34 & -1.51 & 5.63 & -0.22 & -4.7 & -6.24 & 0.35 & -7.71 & -2.23 & -1.28 \\
\hline \multicolumn{11}{|c|}{ QUICK RATIO OF SELECTED PHARMACEUTICAL COMPANIES } \\
\hline & \multicolumn{5}{|c|}{ Large Scale Companies } & \multicolumn{5}{|c|}{ Medium Scale Companies } \\
\hline & $\begin{array}{c}\text { Piramal } \\
\text { Enterprises }\end{array}$ & $\begin{array}{c}\text { Dr. } \\
\text { Reddy's } \\
\text { Lab }\end{array}$ & CIPLA & $\begin{array}{c}\text { Sun } \\
\text { Pharma }\end{array}$ & Ranbaxy & $\begin{array}{c}\text { Jubilant } \\
\text { Life }\end{array}$ & $\begin{array}{l}\text { Cadila } \\
\text { Health }\end{array}$ & Glenmark & Orchid & $\begin{array}{l}\text { Divis } \\
\text { Labs }\end{array}$ \\
\hline Average & 2.44 & 3.2 & 3.1 & 4.25 & 1.69 & 1.91 & 2.11 & 5.02 & 2.63 & 3.07 \\
\hline SD & 0.62 & 0.69 & 0.63 & 2.02 & 0.37 & 0.37 & 0.3 & 2.74 & 0.73 & 0.4 \\
\hline CV & 25.41 & 21.63 & 20.23 & 47.61 & 21.68 & 19.45 & 14.05 & 54.49 & 27.66 & 13.12 \\
\hline Maximum & 3.4 & 3.91 & 3.72 & 7.92 & 2.19 & 2.46 & 2.58 & 8.88 & 3.64 & 3.76 \\
\hline Minimum & 1.43 & 2.15 & 2.11 & 2.57 & 1.21 & 1.23 & 1.79 & 1.56 & 1.78 & 2.56 \\
\hline AGR (\%) & 52.96 & -14.11 & 72.95 & -2.22 & -38.21 & -47.51 & 3.58 & -55.19 & -20.22 & -12.12 \\
\hline $\operatorname{CAGR}(\%)$ & 4.34 & -1.51 & 5.63 & -0.22 & -4.7 & -6.24 & 0.35 & -7.71 & -2.23 & -1.28 \\
\hline
\end{tabular}




\begin{tabular}{|c|c|c|c|c|c|c|c|c|c|c|}
\hline \multicolumn{11}{|c|}{ DEBT-EQUITY RATIO OF SELECTED PHARMACEUTICAL COMPANIES } \\
\hline & \multicolumn{5}{|c|}{ Large Scale Companies } & \multicolumn{5}{|c|}{ Medium Scale Companies } \\
\hline & $\begin{array}{c}\text { Piramal } \\
\text { Enterprises }\end{array}$ & $\begin{array}{l}\text { Dr.Reddy's } \\
\text { Lab }\end{array}$ & CIPLA & $\begin{array}{c}\text { Sun } \\
\text { Pharma }\end{array}$ & Ranbaxy & $\begin{array}{c}\text { Jubilant } \\
\text { Life }\end{array}$ & $\begin{array}{l}\text { Cadila } \\
\text { Health }\end{array}$ & Glenmark & Orchid & $\begin{array}{l}\text { Divis } \\
\text { Labs }\end{array}$ \\
\hline Average & 0.43 & 0.17 & 0.11 & 0.37 & 1.06 & 1.36 & 0.59 & 0.92 & 2.18 & 0.15 \\
\hline SD & 0.26 & 0.12 & 0.08 & 0.58 & 0.84 & 0.44 & 0.2 & 0.75 & 0.85 & 0.15 \\
\hline $\mathrm{CV}$ & 61.3 & 67.87 & 75.55 & 158.28 & 78.78 & 32.7 & 33.24 & 82.3 & 38.91 & 105.32 \\
\hline Maximum & $\mathbf{0 . 8 2}$ & 0.41 & 0.24 & 1.64 & 2.5 & 1.99 & 0.96 & 2.29 & 3.87 & 0.44 \\
\hline Minimum & 0.02 & 0.03 & $\mathbf{0}$ & 0 & 0.01 & 0.74 & 0.27 & 0.22 & 1.31 & 0.01 \\
\hline AGR (\%) & -41.96 & 84.64 & -34.63 & -62.55 & 168.69 & -24.26 & -47.53 & -52.91 & 12.58 & -95.5 \\
\hline $\operatorname{CAGR}(\%)$ & -5.3 & 2.52 & -4.16 & -9.36 & 6.7 & -2.74 & -6.25 & -7.25 & 1.19 & -26.66 \\
\hline
\end{tabular}

Source: computed

The current ratio in selected large scale and medium scale pharmaceutical companies in India has been shown in Table 1.2.The average current ratio among the large scale pharmaceutical companies was the maximum of 4.25 times in sun pharma and the minimum of 1.69 times in Ranbaxy. The standard deviation of 2.02 times in sun pharma shows a high fluctuation of selected large scale pharmaceutical companies under study

The coefficient of variation has found to be the maximum of 47.61 times in sun pharma and the minimum of 20.23 times in cipla. The AGR was the maximum of $72.95 \%$ in cipla and the minimum of $-38.21 \%$ in Ranbaxy. The CAGR was the maximum of $5.63 \%$ in CIPLA and the minimum of $-4.70 \%$ in Ranbaxy.

The average current ratio among the medium scale pharmaceutical companies was the maximum of 5.02 times in Glenmark and the minimum of 1.91 times in Jubiliant life. The standard deviation of 2.74 times in Glenmark shows a high fluctuation of selected companies under the study. The coefficient of variation has found to be the maximum of 54.49 times in Glenmark and the minimum of 13.12 times in Divis labs. The AGR was the maximum of $12.12 \%$ in Divis Labs and the minimum of $-55.19 \%$ in Glenmark. The CAGR was the maximum of $0.35 \%$ in Cadila health and the minimum of $-7.71 \%$ in Glenmark. 


\section{Table 1.3}

TURNOVER ANALYSIS OF SELECTED PHARMACEUTICAL COMPANIES

The average Working Capital Turnover ratio among the large scale pharmaceutical companies were the maximum of 67.96 times in Sun Pharma and the minimum of 31.25 times in Ranbaxy. The standard deviation of 32.72 times in Sun Pharma shows a high fluctuation of selected large scale pharmaceutical companies under study. The coefficient of variation has found to be the maximum of 48.14 times in sun pharma and the minimum of 29.83 times in Dr.Reddy's labs. The AGR was the maximum of $36.66 \%$ in Sun Pharma and the minimum of $-25.15 \%$ in Ranbaxy. The CAGR was the maximum of $11.61 \%$ inPiramal Enter and the minimum of $-2.85 \%$ in Ranbaxy.

The Working Capital Turnover ratio in selected large scale and medium scale pharmaceutical companies in India has been shown in Table 1.3. The average Working Capital Turnover ratio among the medium scale pharmaceutical companies was the maximum of 86.85 times in Glenmark and the minimum of 26.43 times in Cadila Health. The standard deviation of 64.52 times in Glenmark shows a high fluctuation of selected companies under the study. The coefficient of variation has found to be the maximum of 74.29 times in Glenmark and the minimum of 16.04 times in Divis labs. The AGR was the maximum of $6.35 \%$ in Cadila and the minimum of $-65.18 \%$ in Glenmark. The CAGR was the maximum of $0.62 \%$ in Cadila and the minimum of -10.01 $\%$ inGlenmark.

Table 1.3 Turnover Analyses of Selected Pharmaceutical Companies

\begin{tabular}{|c|c|c|c|c|c|c|c|c|c|c|}
\hline \multicolumn{11}{|c|}{ WORKING CAPITAL TURNOVER RATIO OF SELECTED PHARMACEUTICAL COMPANIES } \\
\hline & \multicolumn{5}{|c|}{ Large Scale Companies } & \multicolumn{5}{|c|}{ Medium Scale Companies } \\
\hline & $\begin{array}{c}\text { Piramal } \\
\text { Enterprises }\end{array}$ & $\begin{array}{c}\text { Dr.Reddy's } \\
\text { Lab } \\
\end{array}$ & CIPLA & $\begin{array}{c}\text { Sun } \\
\text { Pharma }\end{array}$ & Ranbaxy & $\begin{array}{c}\begin{array}{c}\text { Jubilant } \\
\text { Life }\end{array} \\
\end{array}$ & $\begin{array}{l}\text { Cadila } \\
\text { Health }\end{array}$ & Glenmark & Orchid & $\begin{array}{l}\text { Divis } \\
\text { Labs } \\
\end{array}$ \\
\hline Average & 38.73 & 61.42 & $\mathbf{5 0 . 5 4}$ & 67.96 & 31.25 & 27.25 & 26.43 & 86.85 & $\mathbf{5 9 . 4 3}$ & 48.51 \\
\hline SD & 17.21 & 18.32 & 7.85 & 32.72 & 12.37 & 10.95 & 7.18 & 64.52 & 9.72 & 7.78 \\
\hline $\mathrm{CV}$ & 44.44 & 29.83 & 15.54 & 48.14 & 39.57 & 40.2 & 27.19 & 74.29 & 16.35 & 16.04 \\
\hline Maximum & 66.1 & 89.51 & 61.44 & 127.23 & 63.4 & 51.03 & 37.03 & 220.62 & 72.82 & 61.5 \\
\hline Minimum & 19.25 & 39.52 & 41.07 & 31.09 & 19.34 & 9.82 & 17.92 & 18.33 & 44.12 & 37.29 \\
\hline AGR (\%) & 199.88 & -9.85 & 2.39 & 36.66 & -25.15 & -60.82 & 6.35 & -65.18 & -16.72 & -7.3 \\
\hline CAGR(\%) & 11.61 & -1.03 & 0.24 & 3.17 & -2.85 & -8.95 & 0.62 & -10.01 & -1.81 & -0.75 \\
\hline
\end{tabular}


IRA-International Journal of Management \& Social Sciences

\begin{tabular}{|c|c|c|c|c|c|c|c|c|c|c|}
\hline \multicolumn{11}{|c|}{ INVENTORY COLLECTION PERIOD OF SELECTED PHARMACEUTICAL COMPANIES } \\
\hline & \multicolumn{5}{|c|}{ Large Scale Companies } & \multicolumn{5}{|c|}{ Medium Scale Companies } \\
\hline & $\begin{array}{c}\text { Piramal } \\
\text { Enterprises }\end{array}$ & $\begin{array}{l}\text { Dr.Reddy's } \\
\text { Lab }\end{array}$ & CIPLA & $\begin{array}{c}\text { Sun } \\
\text { Pharma }\end{array}$ & Ranbaxy & $\begin{array}{c}\text { Jubilant } \\
\text { Life }\end{array}$ & $\begin{array}{l}\text { Cadila } \\
\text { Health }\end{array}$ & Glenmark & Orchid & $\begin{array}{l}\text { Divis } \\
\text { Labs }\end{array}$ \\
\hline Average & 61 & 87 & 142 & 101 & 100 & 76 & 87 & 84 & 216 & 225 \\
\hline SD & 17 & 11 & 14 & 31 & 24 & 10 & 14 & 30 & 49 & 55 \\
\hline $\mathrm{CV}$ & 27 & 12 & 10 & 31 & 24 & 14 & 16 & 35 & 23 & 24 \\
\hline Maximum & 99 & 101 & 167 & 148 & 141 & 89 & 112 & 128 & 301 & 353 \\
\hline Minimum & 38 & 71 & 125 & 69 & 56 & 58 & 71 & 42 & 149 & 159 \\
\hline AGR (\%) & -38 & 19 & -2 & 38 & 3 & 15 & -6 & -59 & -27 & 12 \\
\hline CAGR(\%) & -5 & 2 & $\mathbf{0}$ & 3 & $\mathbf{0}$ & 1 & -1 & -9 & -3 & 1 \\
\hline \multicolumn{11}{|c|}{ ACCOUNTS RECEIVABLE PERIOD OF SELECTED PHARMACEUTICAL COMPANIES } \\
\hline & \multicolumn{5}{|c|}{ Large Scale Companies } & \multicolumn{5}{|c|}{ Medium Scale Companies } \\
\hline & $\begin{array}{c}\text { Piramal } \\
\text { Enterprises }\end{array}$ & $\begin{array}{l}\text { Dr.Reddy's } \\
\text { Lab }\end{array}$ & CIPLA & $\begin{array}{c}\text { Sun } \\
\text { Pharma }\end{array}$ & Ranbaxy & $\begin{array}{c}\text { Jubilant } \\
\text { Life }\end{array}$ & $\begin{array}{l}\text { Cadila } \\
\text { Health }\end{array}$ & Glenmark & Orchid & $\begin{array}{l}\text { Divis } \\
\text { Labs }\end{array}$ \\
\hline Average & 45 & 105 & 101 & 76 & 91 & 57 & 60 & 130 & 120 & 95 \\
\hline SD & 7 & 14 & 19 & 21 & 33 & 8 & 12 & 45 & 59 & 11 \\
\hline $\mathrm{CV}$ & 16 & 13 & 19 & 28 & 36 & 13 & 20 & 35 & 50 & 12 \\
\hline Maximum & 57 & 127 & 133 & 121 & 170 & 65 & 79 & 188 & 206 & 108 \\
\hline Minimum & 37 & 85 & 72 & 49 & 48 & 45 & 37 & 56 & 19 & 75 \\
\hline $\operatorname{AGR}(\%)$ & -17 & 31 & -26 & -16 & 72 & -26 & 25 & -36 & -67 & -8 \\
\hline CAGR(\%) & -2 & 3 & -3 & -2 & 6 & -3 & 2 & -4 & -11 & -1 \\
\hline
\end{tabular}

Source: computed

Table 1.4 Profitability analyses of selected pharmaceutical companies

The operating profit ratio in selected large scale and medium scale pharmaceutical companies in India has been shown in Table 1.4. The average operating profit ratio among the large scale pharmaceutical companies was the maximum of 37.48 times in Sun Pharma and the minimum of 9.58 times in Ranbaxy. The standard deviation of 23.01 times in Ranbaxy shows a high fluctuation of selected large scale pharmaceutical companies under study. The coefficient of variation has found to be the maximum of 240.15 times in Ranbaxy and the minimum of 9.21 times in Cipla. The AGR was the maximum of 52.13\% in Sun 
Pharma and the minimum of $-81.96 \%$ in Ranbaxy. The CAGR was the maximum of $4.28 \%$ in Sun Pharma and the minimum of $-15.74 \%$ in Rabaxy.

Table 1.4 Profitability analyses of selected pharmaceutical companies

\begin{tabular}{|c|c|c|c|c|c|c|c|c|c|c|}
\hline \multicolumn{11}{|c|}{ OPERATING PROFIT RATIO OF SELECTED PHARMACEUTICAL COMPANIES } \\
\hline & \multicolumn{5}{|c|}{ Large Scale Companies } & \multicolumn{5}{|c|}{ Medium Scale Companies } \\
\hline & $\begin{array}{c}\text { Piramal } \\
\text { Enterprises }\end{array}$ & $\begin{array}{c}\text { Dr. } \\
\text { Reddy's } \\
\text { Lab } \\
\end{array}$ & CIPLA & $\begin{array}{c}\text { Sun } \\
\text { Pharma }\end{array}$ & Ranbaxy & $\begin{array}{c}\text { Jubilant } \\
\text { Life }\end{array}$ & $\begin{array}{l}\text { Cadila } \\
\text { Health }\end{array}$ & Glenmark & Orchid & $\begin{array}{l}\text { Divis } \\
\text { Labs }\end{array}$ \\
\hline Average & 22.84 & 24.09 & 25.64 & 37.48 & 9.58 & 19.8 & 25.32 & 27.21 & 29.97 & 39.85 \\
\hline SD & 7.69 & 7.38 & 2.36 & 7.55 & 23.01 & 5.62 & 4.48 & 7.18 & 14.21 & 4.22 \\
\hline CV & 33.66 & 30.62 & 9.21 & 20.14 & 240.15 & 28.38 & 17.7 & 26.4 & 47.41 & 10.6 \\
\hline Maximum & 40.35 & 39.22 & 28.63 & 52.33 & 33.03 & 27.72 & 35.65 & 42.12 & 68.2 & 47.62 \\
\hline Minimum & 10.85 & 9.65 & 22.28 & 30.52 & -31.74 & 10.57 & 20.26 & 21 & 20.73 & 33.37 \\
\hline $\operatorname{AGR}(\%)$ & -43.38 & 10.74 & 17.68 & 52.13 & -81.96 & -44.07 & 42.08 & 5.5 & 13.3 & 4.82 \\
\hline CAGR(\%) & -5.53 & 1.03 & 1.64 & 4.28 & -15.74 & -5.64 & 3.57 & 0.54 & 1.26 & 0.47 \\
\hline \multicolumn{11}{|c|}{ NET PROFIT RATIO OF SELECTED PHARMACEUTICAL COMPANIES } \\
\hline & \multicolumn{5}{|c|}{ Large Scale Companies } & \multicolumn{5}{|c|}{ Medium Scale Companies } \\
\hline & $\begin{array}{c}\text { Piramal } \\
\text { Enterprises }\end{array}$ & $\begin{array}{c}\text { Dr. } \\
\text { Reddy's } \\
\text { Lab } \\
\end{array}$ & CIPLA & $\begin{array}{c}\text { Sun } \\
\text { Pharma }\end{array}$ & Ranbaxy & $\begin{array}{c}\begin{array}{c}\text { Jubilant } \\
\text { Life }\end{array} \\
\end{array}$ & $\begin{array}{l}\text { Cadila } \\
\text { Health } \\
\end{array}$ & Glenmark & Orchid & $\begin{array}{l}\text { Divis } \\
\text { Labs } \\
\end{array}$ \\
\hline Average & 0.1 & 0.06 & 0.18 & 0.32 & 0.08 & 0.11 & 0.17 & 0.17 & 0.01 & 0.29 \\
\hline SD & 0.08 & 0.04 & 0.02 & 0.07 & 0.13 & 0.05 & 0.05 & 0.06 & 0.17 & 0.07 \\
\hline $\mathrm{CV}$ & 80.37 & 71.59 & 10.56 & 22.32 & 164.42 & 50.89 & 32.26 & 32.55 & 117.96 & 23.12 \\
\hline Maximum & 0.17 & 0.13 & 0.21 & 0.44 & 0.21 & 0.2 & 0.28 & 0.28 & 0.15 & 0.37 \\
\hline Minimum & -0.1 & -0.03 & 0.15 & 0.25 & -0.26 & 0.02 & 0.09 & 0.12 & -0.44 & 0.18 \\
\hline $\operatorname{AGR}(\%)$ & -165.83 & -121.84 & 9.75 & 52.62 & -83.82 & -72.87 & 128.36 & 58.54 & 78.11 & 19.71 \\
\hline $\operatorname{CAGR}(\%)$ & -26.66 & -19.58 & 0.93 & 4.32 & -16.65 & -12.23 & 8.61 & 4.72 & 5.94 & 1.82 \\
\hline
\end{tabular}


IRA-International Journal of Management \& Social Sciences

\begin{tabular}{|c|c|c|c|c|c|c|c|c|c|c|}
\hline \multicolumn{11}{|c|}{ RETURN ON TOTAL ASSETS RATIO } \\
\hline & \multicolumn{5}{|c|}{ Large Scale Companies } & \multicolumn{5}{|c|}{ Medium Scale Companies } \\
\hline & $\begin{array}{c}\text { Piramal } \\
\text { Enterprises }\end{array}$ & $\begin{array}{c}\text { Dr. } \\
\text { Reddy's } \\
\text { Lab }\end{array}$ & CIPLA & $\begin{array}{c}\text { Sun } \\
\text { Pharma }\end{array}$ & Ranbaxy & $\begin{array}{c}\text { Jubilant } \\
\text { Life }\end{array}$ & $\begin{array}{l}\text { Cadila } \\
\text { Health }\end{array}$ & Glenmark & Orchid & $\begin{array}{l}\text { Divis } \\
\text { Labs }\end{array}$ \\
\hline Average & 0.12 & 0.04 & 0.18 & 0.2 & 0.09 & 0.08 & 0.16 & 0.1 & 0.01 & 0.25 \\
\hline SD & 0.09 & $\mathbf{0 . 0 3}$ & 0.04 & 0.06 & 0.12 & 0.04 & 0.04 & $\mathbf{0 . 0 5}$ & 0.08 & 0.06 \\
\hline $\mathbf{C V}$ & 77.15 & 76.17 & 20.37 & 30.6 & $\mathbf{1 3 8 . 0 3}$ & 53.09 & 26.59 & 52.33 & 101.6 & 25.69 \\
\hline Maximum & 0.27 & 0.1 & 0.25 & $\mathbf{0 . 3 2}$ & 0.33 & $\mathbf{0 . 1 3}$ & 0.23 & 0.25 & 0.07 & 0.37 \\
\hline Minimum & -0.02 & -0.02 & 0.14 & 0.1 & -0.15 & 0.01 & 0.09 & 0.05 & -0.21 & 0.14 \\
\hline $\operatorname{AGR}(\%)$ & -105.66 & -123.54 & -27.31 & -33.94 & -91.78 & -87.16 & 79.64 & 0.73 & 80.12 & -4.35 \\
\hline $\operatorname{CAGR}(\%)$ & -12.14 & -15.95 & -3.14 & -4.06 & -22.11 & -18.56 & 6.03 & 0.07 & 6.06 & -0.44 \\
\hline
\end{tabular}

Source: computed

The operating profit ratio in selected large scale and medium scale pharmaceutical companies in India has been shown in Table 1.4. The average operating profit ratio among the large scale pharmaceutical companies was the maximum of 37.48 times in Sun Pharma and the minimum of 9.58 times in Ranbaxy. The standard deviation of 23.01 times in Ranbaxy shows a high fluctuation of selected large scale pharmaceutical companies under study. The coefficient of variation has found to be the maximum of 240.15 times in Ranbaxy and the minimum of 9.21 times in Cipla. The AGR was the maximum of 52.13\% in Sun Pharma and the minimum of $-81.96 \%$ in Ranbaxy. The CAGR was the maximum of $4.28 \%$ in Sun Pharma and the minimum of $-15.74 \%$ in Rabaxy.

The average operating profit ratio among the medium scale pharmaceutical companies was the maximum of 39.85 times in Divis lab and the minimum of 19.80 times in Jubilant Life. The standard deviation of 14.21 times in Orchid shows a high fluctuation of selected companies under the study. The coefficient of variation has found to be the maximum of 47.41 times in Orchid and the minimum of 10.60 times in Divis Labs. The AGR was the maximum of $42.08 \%$ in Cadila Health and the minimum of $-44.07 \%$ in Jubilant. The CAGR was the maximum of $3.57 \%$ in Cadila and the minimum of $-5.64 \%$ in Jubilant. 


\section{Suggestion and Recommendation}

Selected pharmaceutical companies should improve its current ratio above 2 . To improve the current ratio the companies should increase their current assets or decrease their current liabilities. Sufficient quick ratio is maintained by all companies in large scale and medium scale. They should maintain the same in the years to come. Selected companies should increase their borrowing with minimum interest. It uses trading on equity technique to increase wealth of equity shareholders. Working capital is a base for day-to-day operation of business. Companies having low working capital should increase their current assets, for interrupted production. Very high working capital also leads high liquidity but low profitability. So companies should maintain moderate working capital ratio, which leads to high liquidity and profitability. Number of days required to convert inventory into cash is known as inventory collection period. Higher number of days indicates that the company has poor inventory management system. Companies who have highest collection period should concentrate on its inventory management technique, to reduce number of days of inventory collection and then only they can increase their profitability and maintain required working capital. Number of days required to collect cash from debtors is calculated by account receivable period. Companies who have higher days to collect cash from debtors fail to increase their profitability, fail to maintain adequate working capital. So they should follow proper collection technique and increase their liquidity position. Number of days required to pay creditors is calculated by accounts payable period. Companies who have minimum number of days to pay its suppliers, will increase the number of days by means of opting suitable buyer will lead to increase profitability and minimize working capital requirements. Operating cycle period is a period from selling inventories to collecting cash. Minimum number of days of operating cycle indicates that the company has quickly converted its stock into cash. The companies of higher operating cycle period should follow necessary debt collecting techniques to reduce number of days for collecting money from debtors. Companies have highest cash turnover ratio shows that it has good profitability position. It can easily maintain required cash level. So low cash turnover ratio companies should concentrate on increasing cash receipts and delaying cash position as it possible. Companies, who have lowest current asset turnover ratio implies that, they are the companies did not have sales in a quick time. It will decrease the rate of profitability so companies should concentrate to increase the sales. The companies should maintain minimum current liability to total asset ratio. Highest current liability to total asset ratio indicates that the companies need to maintain higher amount of working capital to maintain its short term solvency position. It automatically reduces profitability of companies. Operating profit reveals operational efficiency of business concern. Low operating ratio companies like Ranbaxy, should concentrate on controlling their cost of sales and other operating expenses to revamp its operating ratio. Every stakeholder of business is mainly focusing on net profit of company. It will increase goodwill among the stakeholders. Minimum net profit companies like Orchid, should reduce its operating and non-operating expenses and also adopt proper marketing techniques to increase their sales and profit margin. Return Total Assets Ratio is an indicator, how effectively assets are used to increase its profitability. Low ratio indicates that assets are not efficiently used in business so the companies should plan properly and effectively use the idle assets to increase profitability.

\section{Conclusions}

The study has analyzed the working capital position of selected pharmaceutical companies in India was satisfactory. It can be concluded that the pharmaceutical companies have good liquidity position; their ratios were normally higher 
than ideal ratio. So they can easily meet their short term liabilities and working capital requirement. Secondly solvency position of the pharmaceutical companies were not satisfactory, it would suffer their long term borrowing. So they should improve their debt equity ratio. Conversion periods of working capital components were also longer period of time. It would affect the profitability of companies. So they should reduce their conversion period of for working capital components. So the selected pharmaceutical companies should control their cost of sales and other operating expenses to increase their profitability.

\section{Reference:}

1. Mobeen ur rehman,naveed anjum(2013), "determination of the impact of working capital management on profitability" an empirical study from the cement sector in pakistan asian economic and financial review, 3(3):319- 332.

2. Dr.Gulshan Kumar Global (2013), "Journal of Science Frontier Research" Volume 11, Issue 2, March 2012, pp: 99-120.

3. Muhammad FahadIftikhar, (2013)“'Determinants of working capital management efficiency: Case study of Pakistani automotive and engineering firms listed in Karachi Stock Exchange", Research Journal of Finance and Accounting, Vol.4, No.7, pp: 216-236. 